\title{
Why Have Americans Changed Their Minds about Premarital Sex?
}

\author{
George R. G. Clarke \\ ${ }^{1}$ A.R. Sanchez, Jr. School of Business, Texas A\&M International University, Laredo, TX, USA \\ Correspondence: George Clarke, Texas A\&M International University, 5201 University Boulevard, Laredo, \\ Texas 78041, USA. Tel: 1-956-326-2557. E-mail: GEORGE@GRGCLARKE.COM
}

Received: January 2, 2018

doi:10.5539/ijef.v10n3p120
Accepted: February 5, 2018

Online Published: February 10, 2018

URL: https://doi.org/10.5539/ijef.v10n3p120

\begin{abstract}
Since the turn of the new millennium, Americans' views about sex have become more socially liberal. The percent of Americans who disapproved of pre-marital sex fell by 14 percentage points between 2002 and 2014 and the percent who disapproved of sex between same-sex couples fell by 18 percentage points. In this paper, we ask whether demographic changes can explain these trends. We find generational shifts between people born in the early and later part of the $20^{\text {th }}$ century can explain about 30 percent of the change. Other demographic changes, including decreased religiosity and marital rates, explain an extra 10 to 15 percent of the change. Because these demographic changes will probably continue, Americans' views on these issues will probably become even more liberal in future decades.
\end{abstract}

Keywords: marriage, fertility, religious affiliation, demographic change, United States

\section{Introduction}

Americans' views on many social issues became more liberal in the first decades of the new millennium. In 1996, 27 percent of Americans favored legalizing gay marriage (Pew Research Center, 2017). About 62 percent of Americans did the same in 2017 (Pew Research Center, 2017). In the same way, Americans' views about allowing gay men and lesbians to serve in the armed forces have changed. In 1993, only about 44 percent of Americans thought gay men and lesbians should serve openly (McCabe, 2010). When President Clinton implemented "Don't Ask, Don't Tell" in 1993, allowing gay men and lesbians to serve so long as they did not reveal their sexual orientation, many saw it as a liberal policy. When Congress repealed the policy seventeen years later, 75 percent of Americans believed gay men and lesbians should serve openly. As a result, many saw "Don't Ask, Don't Tell" as a conservative, not a liberal, policy (McCabe, 2010).

Attitudes about sex have also changed. In 2002, 31 percent of Americans said sex between same sex couples was not wrong and 44 percent said the same about premarital sex (Note 1). By 2014, this had increased to 49 percent for sex between same sex couples and 58 percent for premarital sex.

Public opinion about sex can change in two ways. First, public opinion can change because the survey asks the questions to different people in different years. Between the early 2000s and the mid-2010s, people born in the 1980s and 1990s became adults and people from earlier generations died. As a result, the survey population was different in 2014 than in 2002. One notable change is the silent generation, born between 1925 and 1945, made up a smaller share of the population in 2014 than in 2002. Another is that millennials, born between 1980 and 2000 , made up a greater share.

Second, individuals who stay in the survey can change their minds. People who once disapproved of sex between unmarried or same-sex partners might start approving of them. Many people, however, argue individuals do not often change their opinions, especially about controversial social issues such as sex (Ruggles, 2015). If individuals do not change their views often, and only do so in response to significant external pressure, public opinion should change slowly.

Although individuals might not change their minds often, they might do so when their external circumstances change. Two changes that might be important are changes in religious beliefs and in marital status. Religious beliefs affect views about sex. Members of fundamentalist Protestant churches are more likely to hold socially conservative views about sex between same sex and unmarried couples - that is, believe sex between these couples are wrong - than members of other religious groups. In contrast, religiously unaffiliated people are more likely to have socially liberal views on these issues - that is, believe sex between these couples are not wrong. 
This could be important because more people were religiously unaffiliated and fewer people belonged to fundamentalist Protestant churches in 2014 than in 2002.

Individuals' experiences with getting and staying married also changed in the new millennium. Age at first marriage has increased (Anderson \& Payne, 2016). Because of this, and high divorce rates, married people made up less of the population in 2014 than they did in 2002. As individuals spend more time single or divorced, their views about whether sex outside marriage is acceptable might change. Consistent with this, married and widowed people are less likely to say sex between unmarried couples is not wrong than divorced or single people are

Although changing opinions about sex might affect the age profile of the adult population in the long-run, the immediate effect should be small. In contrast, changes in religious affiliation and marital status might be the result of, rather than the cause of, changing views about sex. Individuals might change churches or stop going altogether, for example, if they disagree with their institution's positions on social issues such as sex and marriage. Individuals' opinions about whether sex is acceptable outside marriage might also affect their marriage and divorce decisions. Because of this, it is important to be careful when interpreting results about how religion and marital status affect opinions about sex.

This paper looks at whether changing demographics can explain why Americans became more accepting of sex between unmarried and same-sex couples between 2002 and 2014. The results suggest the increase in the share of the population born in the last decades of the $20^{\text {th }}$ century and the decrease in the share born earlier are important. They explain 30 percent of the changes in public opinion. Other demographic changes, including in religious affiliation and marital status, explain another 10 to 15 percent. The remaining 55 to 60 percent of the changes are independent of these demographic trends.

\section{How Have Opinions about Sex Changed?}

Many people argue individuals resist changing their opinions about sensitive topics. Discussing changing views about marriage and sex, Ruggles (2015), for example, writes:

"Attitudes are ordinarily a barrier to change, not a cause of change: there must be a source of exogenous pressure for people to reject the values with which they were raised." (Ruggles, 2015, p. 1807).

Opinions affected by religious beliefs, such as views about sex, might be especially rigid (Note 2).

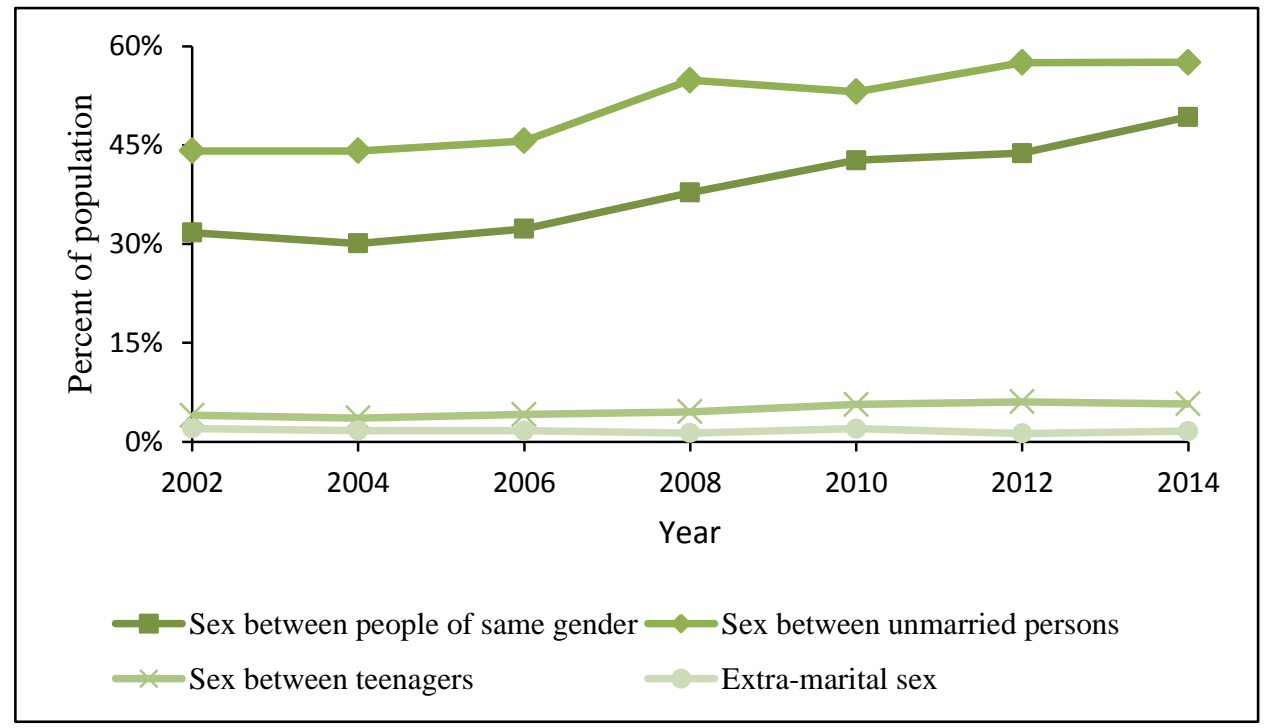

Figure 1. Percent of population saying sex between certain people is not wrong

Despite the idea that individuals' opinions are stable, public opinion about premarital sex and sex between same-sex couples became much more liberal in the early part of the new millennium. In 2002, 31 percent of Americans in the General Social Survey said sex between same-sex couples was not wrong (see Figure 1). By 2014, 49 percent of Americans said the same. Over the same period, Americans also became less concerned about premarital sex. Between 2002 and 2014, the percent of Americans who said premarital sex was not wrong 
went from 44 percent to 58 percent.

One way to explain the rapid change in public opinion, despite individuals' rigid views, is the population was different in 2002 than it was in 2014. Later surveys include people born late in the $20^{\text {th }}$ Century who were too young for the earlier surveys. Further, the earlier surveys include people born earlier who died after 2002 (Note 3). In 2002, 21 percent of the sample were members of the silent generation born between 1925 and 1945, and only 7 percent were millennials born between 1980 and 2000. By 2014, only 13 percent were members of the silent generation but 28 percent were millennials. Because millennials have more liberal views about both premarital sex and sex between people of the same sex than people born earlier (see Table 1), public opinion should be more liberal in later surveys. That is, the shift in public opinion might be due to changes in the population rather than changes in individuals' opinions.

Another demographic change that might have affected opinions about sex between same-sex and unmarried couples is the population became less religious in the early part of the new millennium. The number of people who do not belong to any religious group has grown and the number who belong to fundamentalist Protestant churches has fallen (see Table 1) (Note 4). This could be important because members of fundamentalist Protestant churches were much less likely to say sex between unmarried and same-sex couples were not wrong (40 percent and 21 percent) than people with no religious affiliation ( 80 percent and 72 percent).

Table 1. Changing demographics between 2002 and 2014

\begin{tabular}{|c|c|c|c|c|}
\hline & $\begin{array}{l}\% \text { of survey } \\
\text { in } 2002\end{array}$ & $\begin{array}{l}\% \text { of survey } \\
\text { in } 2014\end{array}$ & $\begin{array}{l}\% \text { saying sex between unmarried } \\
\text { couples is not wrong in } 2015\end{array}$ & $\begin{array}{c}\% \text { saying sex between same sex } \\
\text { couples is not wrong in } 2015\end{array}$ \\
\hline \multicolumn{5}{|l|}{ Birth Year } \\
\hline Silent Generation & $20.9 \%$ & $12.6 \%$ & $37.8 \%$ & $30.0 \%$ \\
\hline Millennials & $6.7 \%$ & $28.1 \%$ & $64.6 \%$ & $64.3 \%$ \\
\hline \multicolumn{5}{|l|}{ Religion } \\
\hline Fundamentalist Protestant & $27.9 \%$ & $22.4 \%$ & $39.5 \%$ & $21.4 \%$ \\
\hline Not Affiliated & $14.0 \%$ & $20.8 \%$ & $79.7 \%$ & $71.9 \%$ \\
\hline \multicolumn{5}{|l|}{ Marital Status } \\
\hline Married & $54.3 \%$ & $52.8 \%$ & $55.4 \%$ & $45.2 \%$ \\
\hline Divorced & $14.9 \%$ & $15.2 \%$ & $60.0 \%$ & $47.8 \%$ \\
\hline Never Married & $24.3 \%$ & $26.2 \%$ & $64.1 \%$ & $61.8 \%$ \\
\hline
\end{tabular}

Source: Authors' calculations based on General Social Surveys (Smith et al., 2015).

A final demographic change that might have affected opinions about premarital sex is married people made up less of the population after 2002. Age at first marriage increased, cohabitation became more common, and divorce rates remained high in the new Millennium (Lundberg et al., 2016; Stevenson \& Wolfers, 2007). This led to a modest decrease in the share of the population that is married and a modest increase in the share that is unmarried between 2002 and 2014 (see Table 1).

This could affect public opinion because unmarried people have more liberal views about premarital sex and sex between people of the same sex than married people do. In 2014, 64 percent and 62 percent of unmarried individuals said premarital sex and sex between same-sex couples were not wrong. About 55 percent and 45 percent of married individuals said the same. This is probably not surprising. Unmarried individuals, especially those living with a partner, would seem more likely to accept sex between unmarried couples.

Changing opinions about sex should not affect the generational distributions of the earlier and later surveys. Although changing views about sex might affect marriages or births in the long-run, it would take time for this to affect the sample. Even if changing beliefs affected marriage or birth decisions in 2002, children born after 2002 will be too young for even the final 2014 survey.

In contrast, changing views about sex might affect individuals' religious affiliation or marital status. Kinnaman (2011) suggests concern about the church's views about sexuality might have caused young Christians to leave the church (Note 5). Jones (2016, p. 132) also notes 31 percent of millennials who left the religion they were brought up in said "negative teachings about or treatment of gay and lesbian people were important factors in their disaffiliation from religion." In a similar way, opinions about premarital sex might also affect marriage decisions. Regnerus (2017), for example, argues millennials have become less interested in marriage because it has become easy to have sex without marrying. As premarital sex becomes more acceptable, marriage rates might fall. 
When trying to assess how religious affiliation and marital status affect opinions it is important to control for other demographic changes. If millennials are less religious or less likely to be fundamentalist Protestant church members than members of older generations, this might result in differences in these groups' opinions. Further, marriage rates are lower for millennials than for earlier generations and so differences between unmarried and married people might be due to differences in the generational composition of these groups. Because of this, it is important to control for birth year and other demographic variables when assessing how religion and marriage affect opinions about sex.

\section{Empirical Analysis}

\subsection{Data}

The study uses data from the General Social Survey (Smith and others, 2015). The data are publicly available on the National Opinion Research Center (NORC) at the University of Chicago website (http://gss.norc.org/). The analysis pools data from 2002 to 2014 to analyze trends since the beginning of the new millennium. The main questions the analysis uses did not change over this period (Note 6). Appendix A shows summary statistics for the dependent and independent variables.

\subsection{Empirical Model}

To see how opinions about premarital sex and sex between same-sex couples changed over time and how they differ between groups, we run regressions of the following form:

$$
y_{i j t}=\alpha+\gamma t+\beta_{j}+\delta_{j} t+\lambda X_{i j}+\varepsilon_{i j}
$$

The underlying dependent variable is the opinion of person $\mathrm{i}$ who belongs to religious group $\mathrm{j}$ at time t. High values mean the person is more likely to believe sex between these groups is 'not wrong'. Individuals' opinions are not observed as continuous variables. Instead the survey includes a categorical variable that takes 4 values: 'always wrong', 'almost always wrong', 'wrong only sometimes', and 'not wrong at all'. We code these between 1 and 4 with 1 representing 'always wrong' and 4 representing 'not wrong at all.' As such, the variable is an ordered variable with higher values suggesting the individual accepts sex between members of those groups.

$$
y_{i j}^{*}=\left\{\begin{array}{cc}
1 & -\infty<y_{i j} \leq \mu_{1} \\
2 & \mu_{1}<y_{i j} \leq \mu_{2} \\
3 & \mu_{2}<y_{i j} \leq \mu_{3} \\
4 & \mu_{3}<y_{i j} \leq \infty
\end{array}\right.
$$

The $\mu$ are nuisance parameters that are estimated along with the main model. We assume the error term, $\varepsilon$, is normally distributed. Because the responses are ordered, but the numerical values are not meaningful in themselves, we estimate the model as an ordered probit model using maximum likelihood estimation.

The base regression, and all subsequent regressions, include a time-trend, $t$, which allows opinions to change over time. A positive coefficient on the time-trend $(\gamma)$ means people are becoming, on average, more likely to say sex between unmarried persons or persons of the same sex are not wrong.

In addition to the regressions that include only the time trend, we also run some regressions including exogenous demographic controls $\left(\mathrm{X}_{\mathrm{ijt}}\right)$ - birth year and race. Birth year might be important if upbringing influences views about sex. If people born in different years have different views about sex, public opinion might change as people born earlier pass away and people born later turn 18. Although changing opinions might affect the respondents' birth cohort and race in the long-run, changing opinions should not affect the composition of the adult population in the 14-year period included in the analysis. After adding these terms, we will re-examine the time trend's coefficient to see how much of the trend the demographic variables can explain.

After including age and race, we add some additional demographic controls including marital status and religious affiliation. In contrast to race and birth year, the additional controls might be affected by changing opinions. The first important set of additional controls are dummies indicating religious affiliation $\left(\beta_{\mathrm{j}}\right)$. The omitted category is fundamentalist Protestant churches. The coefficients, therefore, represent differences between the group j's members' responses and the responses of people who belong to fundamentalist Protestant churches. A positive coefficient means people belonging to that group were more likely to say sex between unmarried persons or persons of the same sex was not wrong than people who belong to fundamentalist Protestant churches.

A second set of additional controls involve marital status. It is possible, for example, that unmarried people have different views about sex than married people do. We interact the dummies with gender to allow marriage to 
affect men's and women's perceptions differently.

The regressions include several additional controls. First, the regression includes dummies indicating the region where the individual lives. Second, it includes a dummy variable representing whether the person has any children. It is possible people's views about premarital sex or sex between same-sex couples might change when they have children. Finally, the regressions include dummies representing educational attainment.

A final set of regressions allow opinions to change differently over time for people with different religious affiliations $\left(\delta_{\mathrm{j}} \mathrm{t}\right)$. Comparing the relative size of two coefficients show which group's perceptions are changing faster. If, for example, the coefficient on group 1's time trend is larger than the coefficient on group 2's, people in group 1's opinions are changing faster than the people in group 2's opinions.

Although the survey also asks about extra-marital sex and sex between teenagers, we do not look at these two issues because opinions about them have changed little and because few Americans believed they were not wrong even in 2014. Few Americans said it was not wrong for a married person to have sex with someone other than their spouse in either 2002 or 2014 (2.0 percent and 1.6 percent). Similarly, although adult Americans became more likely to say sex between teenagers was not wrong between 2002 and 2014 (4.0 percent and 5.8 percent), it remained a minority opinion.

\subsection{Results}

Table 2 presents the main results. Columns 1 and 4 show results from regressions that include only a time trend. Columns 2 and 5 show similar results after including age and race. Contemporaneous changes in opinions about sex should not affect either variable immediately, meaning they should be exogenous. Finally, columns 3 and 6 show results after including some other demographic variables that are less clearly exogenous.

Time Trend. The time trends' coefficients are statistically significant and positive in all regressions. This suggests Americans have become increasingly likely to say sex between unmarried and same-sex couples are not wrong, whether we control for demographic changes or not.

The coefficients on the time trend becomes smaller as we add demographic controls. This suggests changing demographics partly explain changing opinions. Because the ordered probit model is non-linear, it is difficult to interpret the coefficients directly. We therefore estimate how much one year would affect the likelihood each respondent would say sex between same-sex and unmarried couples were not wrong. Averaging the changes over all respondents allows us to estimate how much opinions change in one year.

Before controlling for any demographic changes, the average likelihood a person said sex between same-sex couples was not wrong increased by 1.5 percentage points each year (see Table 3 ). Similarly, the average likelihood that a person said sex between two unmarried people was not wrong increased by 1.1 percentage points each year.

After controlling for birth year and race, the average changes become smaller. The average probabilities that people say sex between same-sex and unmarried couples are not wrong increase by only 1.1 and 0.8 percentage points respectively each year. The results suggest changes in birth year and race explain about 30 percent of the change in opinions.

Finally, after controlling for all additional demographic changes, including religion and marital status, the average changes become even smaller. The average probabilities that people say sex between same-sex and unmarried couples are not wrong increase by only about 0.9 and 0.6 percentage points respectively. The results suggest we can explain about 40 to 45 percent of the change in opinions with birth year, race and the additional variables.

Birth Year. The coefficient on birth year is positive and statistically significant whether the regression includes other demographic controls or not. The positive signs suggests people born later are more likely to say sex between unmarried and same-sex couples are not wrong than people born earlier. On average, people born one year later were about 0.3 percentage points more likely to say premarital sex was not wrong and about 0.5 percentage points more likely to say sex between same-sex couples was not wrong (Note 7).

Religion. People belonging to different religious denominations have different opinions about same-sex and premarital sex even after controlling for marital status, birth year, education, and region. To prevent perfect multicollinearity the regression omits the dummy for fundamentalist Protestants. The coefficients therefore represent the difference in opinion between people affiliated with fundamentalist Protestant churches and people affiliated with other religious groups (Note 8). Statistical significance implies people in that group have different opinions than fundamentalist Protestants. 
Table 2. Perceptions about sex between same-sex and unmarried persons (high values mean approve)

\begin{tabular}{|c|c|c|c|c|c|c|}
\hline \multirow{3}{*}{$\begin{array}{l}\text { Observations } \\
\text { Region Dummies }\end{array}$} & \multicolumn{3}{|c|}{ Same-Sex Couples } & \multicolumn{3}{|c|}{ Unmarried Couples } \\
\hline & 9,042 & 9,017 & 8,880 & 9,305 & 9,274 & 9,130 \\
\hline & No & No & Yes & No & No & Yes \\
\hline \multicolumn{7}{|l|}{ Time Trends } \\
\hline Trend & $\begin{array}{c}0.040^{* * *} \\
(12.12)\end{array}$ & $\begin{array}{c}0.031 * * * \\
(9.06)\end{array}$ & $\begin{array}{c}0.030^{* * * *} \\
(8.36)\end{array}$ & $\begin{array}{c}0.028 * * * \\
(8.95)\end{array}$ & $\begin{array}{c}0.021 * * * \\
(6.47)\end{array}$ & $\begin{array}{c}0.018 * * * \\
(5.42)\end{array}$ \\
\hline \multicolumn{7}{|l|}{ Demographic $^{\text {a }}$} \\
\hline Birth year & & $\begin{array}{c}0.016^{* * * *} \\
(21.01)\end{array}$ & $\begin{array}{c}0.012 * * * \\
(11.90)\end{array}$ & & $\begin{array}{c}0.012 * * * \\
(16.95)\end{array}$ & $\begin{array}{c}0.009 * * * \\
(9.68)\end{array}$ \\
\hline African American & & $\begin{array}{c}-0.625^{* * *} \\
(-16.13)\end{array}$ & $\begin{array}{c}-0.336 * * * \\
(-7.60)\end{array}$ & & $\begin{array}{c}-0.334 * * * \\
(-9.68)\end{array}$ & $\begin{array}{c}-0.065^{*} \\
(-1.67)\end{array}$ \\
\hline Other & & $\begin{array}{c}-0.285^{* * *} \\
(-6.46)\end{array}$ & $\begin{array}{c}-0.321 * * * \\
(-6.64)\end{array}$ & & $\begin{array}{c}-0.166 * * * \\
(-4.01)\end{array}$ & $\begin{array}{c}-0.218^{* * *} \\
(-4.91)\end{array}$ \\
\hline \multicolumn{7}{|l|}{ Religion $^{\mathrm{b}}$} \\
\hline Protestant -- Moderate/Liberal & & & $\begin{array}{c}0.458 * * * \\
(11.22)\end{array}$ & & & $\begin{array}{c}0.403 * * * \\
(11.13)\end{array}$ \\
\hline Catholic & & & $\begin{array}{c}0.647 * * * \\
(15.53)\end{array}$ & & & $\begin{array}{c}0.623 * * * \\
(16.83)\end{array}$ \\
\hline Jewish & & & $\begin{array}{c}1.394 * * * \\
(11.32)\end{array}$ & & & $\begin{array}{c}0.935^{* * *} * \\
(8.67)\end{array}$ \\
\hline No religious affiliation & & & $\begin{array}{c}1.128^{* * * *} \\
(24.89)\end{array}$ & & & $\begin{array}{c}1.107^{* * *} \\
(25.56)\end{array}$ \\
\hline Other religious affiliation & & & $\begin{array}{c}0.573 * * * \\
(10.03)\end{array}$ & & & $\begin{array}{c}0.314 * * * \\
(6.11)\end{array}$ \\
\hline \multicolumn{7}{|l|}{ Marriage $^{c}$} \\
\hline Married Female & & & $\begin{array}{c}0.306 * * * \\
(7.64)\end{array}$ & & & $\begin{array}{c}-0.140 * * * \\
(-3.85)\end{array}$ \\
\hline Widowed Male & & & $\begin{array}{l}-0.019 \\
(-0.16)\end{array}$ & & & $\begin{array}{l}0.099 \\
(1.07)\end{array}$ \\
\hline Widowed Female & & & $\begin{array}{c}0.389 * * * \\
(5.85)\end{array}$ & & & $\begin{array}{c}-0.256 * * * \\
(-4.47)\end{array}$ \\
\hline Divorced/Separate Male & & & $\begin{array}{c}0.311^{* * * *} \\
(5.59)\end{array}$ & & & $\begin{array}{c}0.442^{* * *} * \\
(8.22)\end{array}$ \\
\hline Divorced/Separate Female & & & $\begin{array}{c}0.604 * * * \\
(11.88)\end{array}$ & & & $\begin{array}{c}0.184 * * * \\
(3.95)\end{array}$ \\
\hline Never Married Male & & & $\begin{array}{l}0.205 * * * \\
(3.72)\end{array}$ & & & $\begin{array}{c}0.217 * * * \\
(4.14)\end{array}$ \\
\hline Never Married Female & & & $\begin{array}{c}0.554 * * * \\
(10.46)\end{array}$ & & & $\begin{array}{l}-0.034 \\
(-0.70)\end{array}$ \\
\hline \multicolumn{7}{|l|}{ Children } \\
\hline Has Children & & & $\begin{array}{c}-0.191 * * * \\
(-5.19)\end{array}$ & & & $\begin{array}{l}-0.008 \\
(-0.22)\end{array}$ \\
\hline \multicolumn{7}{|l|}{ Education $^{\mathrm{d}}$} \\
\hline High School Graduate & & & $\begin{array}{l}0.329 * * * \\
(7.55)\end{array}$ & & & $\begin{array}{c}0.181 * * * \\
(4.75)\end{array}$ \\
\hline Some college or associate degree & & & $\begin{array}{c}0.473^{* * * *} \\
(7.50)\end{array}$ & & & $\begin{array}{c}0.235^{* * * *} \\
(4.19)\end{array}$ \\
\hline College Graduate & & & $\begin{array}{c}0.674 * * * \\
(13.03)\end{array}$ & & & $\begin{array}{c}0.187 * * * \\
(4.05)\end{array}$ \\
\hline Post-Graduate Degree & & & $\begin{array}{c}0.924 * * * \\
(15.66)\end{array}$ & & & $\begin{array}{c}0.312^{* * *} * \\
(5.75)\end{array}$ \\
\hline Pseudo R-Squared & 0.008 & 0.043 & 0.145 & 0.004 & 0.020 & 0.084 \\
\hline
\end{tabular}

Source: Authors' calculations based on General Social Surveys (Smith et al., 2015).

$* * *, * *, *$ mean statistically significant at $1 \%, 5 \%$, and $10 \%$ significance levels. ${ }^{a}$ Omitted category is White.

${ }^{\mathrm{b}}$ Omitted category is Fundamentalist Protestant. ${ }^{\mathrm{c}}$ Omitted category is married males. ${ }^{\mathrm{d}}$ Omitted category is less than high school

Note. Regressions are ordered probit regression. Positive signs mean an increase in the variable increases the likelihood the respondent says that type of sexual relationship is not wrong. Regressions with region dummies include 9 census regions (New England; Middle Atlantic; E. North Central; W. North Central; South Atlantic; E. South Central; W. South Central; Mountain; and Pacific). 
Table 3. Average change in likelihood a person says each type of sex is "Not Wrong" of one additional year

\begin{tabular}{lccc}
\hline & No controls & Age and Race only & All Controls \\
\hline Same-sex & $1.11 \%$ & $0.80 \%$ & $0.63 \%$ \\
Premarital sex & $1.52 \%$ & $1.11 \%$ & $0.93 \%$ \\
\hline
\end{tabular}

Note. Average probabilities are calculated by adding one additional year to each person in the samples survey year and then calculating the estimated probability that the person says that sex between two people of the same sex or two unmarried people is 'not wrong'. The estimated probabilities are then averaged over all respondents.

Fundamentalist Protestants are less likely to say sex between two people of the same sex and sex between unmarried persons are 'not wrong' than people belonging to other religious groups. All differences are statistically significant. People who reported no religious affiliation and people who were Jewish were more likely to say sex between same sex and unmarried couples are 'not wrong' than others including fundamentalist Protestants (Note 9).

Fundamentalist Protestants have different opinions than other religious groups' members (see Table 4). After controlling for other differences, the average probability a fundamentalist Protestant said sex between two people of the same sex was not wrong was 22 percent. In comparison, the average probabilities were 36 percent for other Protestants, 40 percent for people of other faiths, 43 percent for Catholics, 59 percent for people not affiliated with any religious group, and 68 percent for Jews. The probability a fundamentalist Protestant said sex between unmarried couples was not wrong was 34 percent compared with 45 percent for people of other faiths, 49 percent for other Protestants, 57 percent for Catholics, 68 percent for Jews, and 74 percent for people who do not belong to any religious group.

Table 4. Average probability that person says each type of sex is "Not Wrong"

\begin{tabular}{lcc}
\hline & Same Sex & Premarital \\
\hline Protestant-fundamentalist & $22 \%$ & $34 \%$ \\
Protestant-other & $36 \%$ & $49 \%$ \\
Catholic & $43 \%$ & $57 \%$ \\
Jewish & $68 \%$ & $68 \%$ \\
None & $59 \%$ & $74 \%$ \\
Other & $40 \%$ & $45 \%$ \\
\hline
\end{tabular}

Note. Average probabilities are calculated by assuming that each person in the sample is of that faith and then calculated the estimated probability that the person says that sex between two people of the same sex or two unmarried people is 'not wrong'. The estimated probabilities are then averaged over all respondents.

Marital Status. Marital status and gender are correlated with views about sex between unmarried and same-sex couples. Women are consistently more likely to say sex between same-sex couples is not wrong and less likely to say premarital sex is not wrong than are men. This is true when we compare married women with married men, widowed women with widowed men, never-married women with never-married men, or divorced women with divorced men. The differences are statistically significant at a 10 percent level or higher in all cases. In addition, people who are married or widowed are less likely to say sex between same-sex and unmarried couples are not wrong than are never married or divorced people of the same sex.

Other factors. The results suggest other factors are also correlated with opinions about sex. People with children are less likely to say sex between same sex couples is not wrong than people with no children — but give similar answers for premarital sex. Second, better educated people are generally more likely to say sex between both groups are not wrong than are less well educated people. Finally, white people are less likely to say sex between both groups are not wrong than African American or other people. 
Table 5. Perceptions about sex between people of the same sex

\begin{tabular}{|c|c|c|c|c|}
\hline \multirow[b]{3}{*}{ Observations } & (1) & (2) & (3) & (4) \\
\hline & \multicolumn{4}{|c|}{ Opinions about sex between people of the same sex } \\
\hline & 8,880 & 8,880 & 8,880 & 8,880 \\
\hline Regional Dummies & Yes & Yes & Yes & Yes \\
\hline Additional control variables (see Table 2) & Yes & Yes & Yes & Yes \\
\hline \multicolumn{5}{|l|}{ Religion $^{\text {a }}$} \\
\hline Protestant -- Moderate/Liberal & $\begin{array}{c}0.458 * * * \\
(11.22)\end{array}$ & $\begin{array}{c}0.352 * * * \\
(5.19)\end{array}$ & $\begin{array}{c}0.955^{* * * *} \\
(7.96)\end{array}$ & $\begin{array}{c}0.934 * * * \\
(7.42)\end{array}$ \\
\hline Catholic & $\begin{array}{c}0.647 * * * \\
(15.53)\end{array}$ & $\begin{array}{c}0.541 * * * \\
(7.91)\end{array}$ & $\begin{array}{c}1.148 * * * \\
(9.53)\end{array}$ & $\begin{array}{c}1.123^{* * *} * \\
(8.92)\end{array}$ \\
\hline Jewish & $\begin{array}{c}1.394 * * * \\
(11.32)\end{array}$ & $\begin{array}{c}1.289 * * * \\
(9.59)\end{array}$ & $\begin{array}{c}1.893 * * * \\
(11.33)\end{array}$ & $\begin{array}{c}2.047^{* * * *} \\
(7.86)\end{array}$ \\
\hline No religious affiliation & $\begin{array}{c}1.128 * * * \\
(24.89)\end{array}$ & $\begin{array}{c}1.021 * * * \\
(14.36)\end{array}$ & $\begin{array}{c}1.640 * * * \\
(13.41)\end{array}$ & $\begin{array}{c}1.680^{* * *} \\
(12.69)\end{array}$ \\
\hline Other religious affiliation & $\begin{array}{c}0.573 * * * \\
(10.03)\end{array}$ & $\begin{array}{c}0.465^{* * * *} \\
(5.83)\end{array}$ & $\begin{array}{c}1.076^{* * * *} \\
(8.45)\end{array}$ & $\begin{array}{c}1.115^{* * * *} \\
(7.40)\end{array}$ \\
\hline Protestant -- Fundamentalist, attends services infrequently & & & $\begin{array}{c}0.870^{* * *} \\
(6.63)\end{array}$ & $\begin{array}{c}0.870^{* * *} \\
(6.63)\end{array}$ \\
\hline \multicolumn{5}{|l|}{ Time Trends } \\
\hline Trend & $\begin{array}{c}0.030^{* * * *} \\
(8.36)\end{array}$ & & & \\
\hline Trend*Not Fundamentalist Protestant & & $\begin{array}{c}0.034 * * * \\
(8.29)\end{array}$ & $\begin{array}{c}0.034 * * * \\
(8.38)\end{array}$ & \\
\hline Trend*Fundamentalist Protestant & & $\begin{array}{c}0.018 * * \\
(2.35)\end{array}$ & & \\
\hline Trend*Fundamentalist attends services infrequently & & & $\begin{array}{c}0.022 * * \\
(2.53)\end{array}$ & $\begin{array}{c}0.022 * * \\
(2.52)\end{array}$ \\
\hline Trend*Fundamentalist attends services frequently & & & $\begin{array}{l}0.018 \\
(1.22)\end{array}$ & $\begin{array}{l}0.018 \\
(1.22)\end{array}$ \\
\hline Trend*Protestant -- Moderate/Liberal & & & & $\begin{array}{c}0.038^{* * *} * \\
(5.17)\end{array}$ \\
\hline Trend*Catholic & & & & $\begin{array}{c}0.038 * * * \\
(5.49)\end{array}$ \\
\hline Trend*Jewish & & & & $\begin{array}{l}0.009 \\
(0.29)\end{array}$ \\
\hline Trend*No religious affiliation & & & & $\begin{array}{c}0.028 * * * \\
(3.32)\end{array}$ \\
\hline Trend*Other religious affiliation & & & & $\begin{array}{c}0.029 * * \\
(2.39)\end{array}$ \\
\hline Pseudo R-Squared & 0.145 & 0.145 & 0.156 & 0.156 \\
\hline
\end{tabular}

Source: Authors' calculations based on General Social Surveys (Smith et al., 2015).

Note. Regressions are ordered probit regression. A positive sign means that an increase in that variable will increase the likelihood that the respondent says that that type of sexual relation is not wrong. All regressions include 9 regional variables based on census regions (New England; Middle Atlantic; E. North Central; W. North Central; South Atlantic; E. South Central; W. South Central; Mountain; and Pacific) and the additional control variables shown in Table 2. 
Table 6. Perceptions about sex between unmarried persons

\begin{tabular}{|c|c|c|c|c|}
\hline & (1) & (2) & (3) & (4) \\
\hline & \multicolumn{4}{|c|}{ Opinions about sex between unmarried persons } \\
\hline Observations & 9,130 & 9,130 & 9,130 & 9,130 \\
\hline Regional Dummies & Yes & Yes & Yes & Yes \\
\hline Additional control variables (see Table 2). & Yes & Yes & Yes & Yes \\
\hline \multicolumn{5}{|l|}{ Religion $^{\mathrm{a}}$} \\
\hline Protestant -- Moderate/Liberal & $\begin{array}{c}0.403 * * * \\
(11.13)\end{array}$ & $\begin{array}{c}0.482 * * * \\
(8.24)\end{array}$ & $\begin{array}{c}1.090 * * * \\
(12.41)\end{array}$ & $\begin{array}{c}1.141 * * * \\
(12.08)\end{array}$ \\
\hline Catholic & $\begin{array}{c}0.623 * * * \\
(16.83)\end{array}$ & $\begin{array}{c}0.702 * * * \\
(11.88)\end{array}$ & $\begin{array}{c}1.315^{* * *} \\
(14.90)\end{array}$ & $\begin{array}{c}1.296^{* * * *} \\
(13.73)\end{array}$ \\
\hline Jewish & $\begin{array}{c}0.935^{* * * *} \\
(8.67)\end{array}$ & $\begin{array}{c}1.014 * * * \\
(8.65)\end{array}$ & $\begin{array}{c}1.619 * * * \\
(12.07)\end{array}$ & $\begin{array}{c}1.372 * * * \\
(6.33)\end{array}$ \\
\hline No religious affiliation & $\begin{array}{c}1.107 * * * \\
(25.56)\end{array}$ & $\begin{array}{c}1.188^{* * * *} \\
(18.59)\end{array}$ & $\begin{array}{c}1.815^{* * * *} \\
(19.78)\end{array}$ & $\begin{array}{c}1.778^{* * *} \\
(16.54)\end{array}$ \\
\hline Other religious affiliation & $\begin{array}{c}0.314^{* * * *} \\
(6.11)\end{array}$ & $\begin{array}{c}0.395 * * * \\
(5.67)\end{array}$ & $\begin{array}{c}1.008 * * * \\
(10.55)\end{array}$ & $\begin{array}{c}1.014^{* * * *} \\
(8.45)\end{array}$ \\
\hline Protestant -- Fundamentalist, attends services infrequently & & & $\begin{array}{c}0.959^{* * *} * \\
(9.79)\end{array}$ & $\begin{array}{c}0.960^{* * * *} \\
(9.80)\end{array}$ \\
\hline \multicolumn{5}{|l|}{ Time Trends } \\
\hline Trend & $\begin{array}{c}0.018^{* * * *} \\
(5.42)\end{array}$ & & $\begin{array}{c}0.015^{* * * *} \\
(3.78)\end{array}$ & \\
\hline Trend*Not Fundamentalist Protestant & & $\begin{array}{c}0.015 * * * \\
(3.69)\end{array}$ & & \\
\hline Trend*Fundamentalist Protestant & & $\begin{array}{c}0.027 * * * \\
(4.38)\end{array}$ & & \\
\hline Trend*Fundamentalist attends services infrequently & & & $\begin{array}{c}0.032 * * * \\
(4.11)\end{array}$ & $\begin{array}{c}0.032 * * * \\
(4.11)\end{array}$ \\
\hline Trend*Fundamentalist attends services frequently & & & $\begin{array}{c}0.030 * * * \\
(2.83)\end{array}$ & $\begin{array}{c}0.030^{* * * *} \\
(2.84)\end{array}$ \\
\hline Trend*Protestant -- Moderate/Liberal & & & & $\begin{array}{l}0.007 \\
(1.00)\end{array}$ \\
\hline Trend*Catholic & & & & $\begin{array}{c}0.018 * * * \\
(2.71)\end{array}$ \\
\hline Trend*Jewish & & & & $\begin{array}{c}0.055^{*} \\
(1.94)\end{array}$ \\
\hline Trend*No religious affiliation & & & & $\begin{array}{c}0.020^{* *} \\
(2.22)\end{array}$ \\
\hline Trend*Other religious affiliation & & & & $\begin{array}{l}0.014 \\
(1.25)\end{array}$ \\
\hline Pseudo R-Squared & 0.0836 & 0.0837 & 0.102 & 0.102 \\
\hline
\end{tabular}

Source: Authors' calculations based on General Social Surveys (Smith et al., 2015).

Note. Regressions are ordered probit regression. A positive sign means that an increase in that variable will increase the likelihood that the respondent says that that type of sexual relation is not wrong. All regressions include 9 regional variables based on census regions (New England; Middle Atlantic; E. North Central; W. North Central; South Atlantic; E. South Central; W. South Central; Mountain; and Pacific) and the additional control variables shown in Table 2.

Time Trends by Religion. As a final exercise, we look at whether the people who belong to different religious groups' views have converged or diverged since 2002. In particular, we look at whether fundamentalist Protestant's views are changing faster or slower than other groups' views. To see if this is the case, we run three more regressions for each dependent variable (see Table 5 and Table 6). In column 2, we let fundamentalist Protestant's views change at a different rate than everyone else's views (that is, everyone who is not a fundamentalist Protestant). In column 3, we look at differences between fundamentalist Protestants who attend church at least once a week, fundamentalist Protestants who attend church less than once a week, and everyone else. In the final regression, we allow each group's opinions to follow different trends. 
In the first regression for opinions about sex between same sex couples, the coefficients on the time trends are 0.18 for fundamentalist Protestants and 0.34 for others (see column 2 in Table 5). The positive coefficients show both groups' members have become more likely to say sex between people of the same sex was not wrong. Fundamentalist Protestant's opinions, however, have changed more slowly than others' opinions (Note 10). The percentage of fundamentalist Protestants who said sex between same-sex couples was not wrong increased by 1.4 percentage points each year compared with 1.7 percentage points each year for others.

For premarital sex, fundamentalist Protestants' views have changed more, not less, than others' views (see column 2 in Table 6) (Note 11). Although the coefficient is larger for fundamentalist Protestants, the non-linear model means the percentage of people who said premarital sex was not wrong increased by 1.4 percentage points each year for both groups. If, however, we look at the percent of people who said it was not wrong or only sometimes wrong, then opinions for fundamentalist Protestants changed more than others' opinions (1.6 percentage points per year compared with 1.2 percentage points per year).

An interesting question is whether devout fundamentalist Protestants' opinions have changed more or less than less devout fundamentalist Protestants. We separate the sample of fundamentalist Protestants into those who go to church at least once a week and those who go a few times each month or each year. We include two dummies indicating how often fundamentalist Protestants attend church and we interact the dummies with time trends to see whether the two groups' opinions are diverging (see columns 3 of Tables 5 and 6).

Fundamentalist Protestants who go to church less often are more likely to say sex between unmarried and same-sex couples are not wrong than fundamentalist Protestants who go to church more often. The coefficients suggest fundamentalist Protestants who attend church occasionally are about 21 percentage points more likely to say sex between same-sex couples is not wrong than fundamentalist Protestants who attend church more often (32 percent compared with 11 percent) and 30 percentage points more likely to say sex between unmarried couples is not wrong (44 percent compared with 14 percent).

The views of fundamentalist Protestants who attend church less and more often are evolving similarly. The coefficient estimates are close in both regressions (see column 3 in Table 5 and 6) (Note 12).

As a final exercise, we interact the time trends with all the religious affiliation dummies (see column 4). Most coefficients on the interaction terms are positive and statistically significant. Moreover, the coefficients are larger for most groups than for fundamentalist Protestants in the regressions for sex between same-sex couples but smaller in the regression for opinions about sex between unmarried couples. Overall, the results suggest fundamentalist Protestants' views about sex between same-sex couples are not converging with others' views but their views about premarital sex are converging.

\section{Conclusions}

Americans' opinions about sex changed dramatically in a short time. In 2002, only 31 percent of Americans said sex between same-sex couples was not wrong and only 44 percent said premarital sex was not wrong. By 2014 , 49 percent and 58 percent of Americans said the same. In contrast, most Americans continue to see sex between young teenagers and extramarital sex as wrong.

Demographic changes between 2002 and 2014 might partly explain Americans' changing views about sex. Although all groups of Americans include people with liberal and conservative social views, some groups' members are more socially liberal than others. In the paper, we show many demographic differences stay important even after controlling for other differences. First, Americans born towards the end of the $20^{\text {th }}$ Century have more liberal views about sex between same-sex and unmarried couples than people born earlier. Second, single and divorced people's views on these topics are more liberal than married or widowed people's views. Third, religiously unaffiliated Americans - and Jewish Americans - are more liberal than Americans who belong to other religious groups. Fourth, people who belong to fundamentalist Protestant churches are more conservative.

Changes in the relative sizes of these groups can partly explain increased acceptance of sex between unmarried and same-sex couples. One important change is many millennials entered adulthood between 2002 and 2014, while many Americans born earlier passed away. The generational shift between the surveys accounts for about 30 percent of the increase in the percent of Americans saying sex between same-sex and unmarried couples was not wrong.

The generational shift should be exogenous. Although changing views between 2002 and 2014 might affect future demographics, the effect will not be immediate. That is, changing opinions between 2002 and 2014 should not affect births in the 1980s or deaths among older Americans in the 2000s. As a result, causality runs from 
changing demographics to changing opinions in this case.

Two other demographic changes might also affect Americans' views about sex. First, Americans became less religious after 2002. The percent of Americans who do not belong to any religious group increased from 14 to 21 percent of the population between 2002 and 2014. In addition, the percent of Americans who belong to fundamentalist Protestant churches fell. Because religiously unaffiliated Americans are more socially liberal, while Americans who belong to fundamentalist Protestant churches are more conservative, these changes might affect public opinions about sex. Second, never married Americans made up more of the population - and married Americans made up less-in 2002 than in 2014. Because never married Americans are more liberal about sex than married Americans are, this might also partly explain American's increasingly liberal views about sex. We estimate these, and other demographic changes, explain another ten to fifteen percent of the changes in Americans' views.

Although changes in religious beliefs and marital status might affect views about sex, changing views might also affect religious beliefs and marital status. People who do not believe premarital sex is wrong might be more likely to delay marriage or to live with an unmarried partner. Changing opinions about sex might also affect whether people choose to join conservative churches. As a result, it is difficult to assess causation.

As a final exercise, we looked at whether different religious groups' views are converging. Fundamentalist Protestant's views about premarital sex are changing more quickly than others' views, suggesting their views are converging with other Americans' views. In contrast, their views about sex between same-sex couples changed less than the views of other groups suggesting no convergence in this case.

This study's results suggest views about sex between unmarried and same-sex couples will become more liberal in the future. Socially liberal millennials will continue to reach adulthood for several more years, while socially conservative Americans born earlier in the $20^{\text {th }}$ Century will continue to pass away. Further, the views of people born after 2000 will probably be more like - and possibly more liberal than-millennials' views than they are like older Americans' views. Also, current trends in religious beliefs and marital status will probably continue. Together this will mean Americans' views become even more liberal.

\section{References}

Anderson, L., \& Payne, K. K. (2016). Median age at first marriage, 2014. Retrieved from https://www.bgsu.edu/ncfmr/resources/data/family-profiles/anderson-payne-median-age-first-marriage-fp-1 6-07.html

Jones, R. P. (2016). The end of white Christian America. New York, NY: Simon and Schuster.

Kinnaman, D. (2011). You lost me: Why young Christians are leaving church...And rethinking faith. Grand Rapids, MI: Baker Books.

Lundberg, S., Pollak, R. A., \& Stearns, J. (2016). Family inequality; diverging patterns in marriage, cohabitation, and childbearing. Journal of Economic Perspectives, 30, 79-102. https://doi.org/10.1257/jep.30.2.79

McCabe, B. J. (2010). Public opinion on 'don't ask, don't tell.' FiveThirtyEight. Retreived from https://fivethirtyeight.com/features/public-opinion-on-dont-ask-dont-tell/

Messner, T. (2010). Religion and marality in the same-sex marriage debate. Retreived from http://www.heritage.org/marriage-and-family/report/religion-and-morality-the-same-sex-marriage-debate

Perry, S. L. (2017). Does viewing pornography diminish religiosity over time? Evidence from two-wave panel data. Journal of Sex Research, 54, 214-226. https://doi.org/10.1080/00224499.2016.1146203

Pew Research Center. (2017). Support for same-sex marriage grows, even among groups that had been skepitical. Pew Research Center. Retreived from http://www.people-press.org/2017/06/26/support-for-same-sex-marriage-grows-even-among-groups-that-ha d-been-skeptical/

Price, J., Patterson, R., Regnerus, M., \& Walley, J. (2016). How much more XXX is Generation X consuming? Evidence of changing attitudes and behaviors related to pornography since 1973. Journal of Sex Research, 53, 12-20. https://doi.org/10.1080/00224499.2014.1003773

Regnerus, M. (2017). Cheap sex: The transformation of men, marriage, and monogamy. New York, NY: Oxford University Press.

Ruggles, S. (2015). Patriarchy, power and pay: The transformation of American families, 1800-2015. Demography, 52, 1797-1833. https://doi.org/10.1007/s13524-015-0440-z 
Smith, T. W. (1987). Classifying Protestant denominations. National Opinion Research Center (NORC). Retreieved from http://gss.norc.org/Documents/reports/methodological-reports/MR043.pdf

Smith, T. W., Marsden, P., Hout, M., \& Kim, J. (2015). General social surveys, 1972-2014. National Opinion Research Center (NORC). Retreieved from http://gss.norc.org/documents/codebook/GSSCodebook.pdf

Stevenson, B., \& Wolfers, J. (2007). Marriage and divorce: Changes and the driving forces. Journal of Economic Perspectives, 21, 27-52. https://doi.org/10.1257/jep.21.2.27

\section{Notes}

Note 1. Author's calculations using data from the General Social Survey (Smith et al., 2015).

Note 2. The American Civil Liberties Union's President, John Wimberly, for example, claimed the "primary opposition to same-sex marriage appears to be theologically based" (Messner, 2010). Consistent with this, attitudes differ between people of different faiths and beliefs in the GSS sample (see empirical section).

Note 3. The average age of respondents increased from 45.2 to 47.4 years between 2002 and 2014. However, someone who turned 45 in 2002 was born in 1957 whereas someone who turned 47 in 2014 was born in 1967.

Note 4. Members of fundamentalist Protestant churches fell from 28 to 22 percent of the population between 2002 and 2014. In contrast, people with no religious affiliation increased from 14 to 21 percent.

Note 5. He quotes a friend as suggesting (p. 152) "No one leaves the [Catholic] Church because of the Doctrine of the Immaculate Conception. They leave for pelvic reasons." Kinnaman (2011) also notes 38 percent of people aged 18 to 29 from Christian backgrounds, said it was mostly true that churches are not accepting of gays and lesbians. Others have argued sex might affect religiosity in other ways. Perry (2017), for example, argues people who use pornography subsequently have more doubts about religion and report declining interest in religion. Price and others (2016) note people have become more accepting of, and more likely to use, pornography in recent years.

Note 6. See Appendix N of Smith and others (2015) for a discussion of methodological changes.

Note 7. Before controlling for other demographic variables, the effect of a later birth year is slightly larger. On average, people who were born one year later were about 0.4 percentage points less likely to say premarital sex was not wrong and about 0.6 percentage points less likely to say sex between same-sex couples was not wrong before controlling for other demographic variables.

Note 8 . We have to omit one dummy variable to prevent perfect multicollinearity between the dummies and constant term. As noted above, we classify fundamentalist Protestants based on the classification system discussed in Smith (1987).

Note 9. The differences between people who are Jewish or have no religious affiliation and other groups are statistically significant in all cases at a $1 \%$ level or lower. The differences between people who are Jewish and people who have no religious affiliation are statistically significant for sex between two people of the same sex at a $5 \%$ level, but statistically insignificant for sex between unmarried people.

Note 10 . The difference is statistically significant at a 10 percent significance level ( $\mathrm{p}$-value $=0.051$ ).

Note 11. Once again, the difference is statistically significant.

Note 12. Although the coefficient on the time trends are similar in size for fundamentalist Protestants who attend church occasionally and those who attend more often, the coefficient for those who attend more often is not statistically significant. This make it difficult to interpret the results precisely. 


\section{Appendix A}

\section{Summary Statistics}

\begin{tabular}{|c|c|c|}
\hline Variable & Mean & Std. Dev. \\
\hline \multicolumn{3}{|l|}{ Is homosexual sex wrong? } \\
\hline Always wrong & 0.500 & 0.500 \\
\hline Almost always wrong & 0.039 & 0.195 \\
\hline Sometimes wrong & 0.072 & 0.258 \\
\hline Not wrong at all & 0.389 & 0.488 \\
\hline \multicolumn{3}{|l|}{ Is premarital sex wrong? } \\
\hline Always wrong & 0.233 & 0.423 \\
\hline Almost always wrong & 0.076 & 0.264 \\
\hline Sometimes wrong & 0.176 & 0.381 \\
\hline Not wrong at all & 0.515 & 0.500 \\
\hline \multicolumn{3}{|l|}{ Religion } \\
\hline Protestant -- Fundamentalist & 0.266 & 0.442 \\
\hline Protestant -- Other & 0.218 & 0.413 \\
\hline Catholic & 0.257 & 0.437 \\
\hline Jewish & 0.017 & 0.130 \\
\hline None & 0.168 & 0.374 \\
\hline Other & 0.075 & 0.263 \\
\hline Year & 2007 & 3.933 \\
\hline \multicolumn{3}{|l|}{ Marital Status -- By Gender } \\
\hline Married Male & 0.260 & 0.439 \\
\hline Married Female & 0.292 & 0.455 \\
\hline Widowed Male & 0.010 & 0.101 \\
\hline Widowed Female & 0.045 & 0.207 \\
\hline Divorced Male & 0.061 & 0.238 \\
\hline Divorced Female & 0.085 & 0.278 \\
\hline Single Male & 0.128 & 0.334 \\
\hline Single Female & 0.119 & 0.324 \\
\hline Birth Year & 1962 & 17.213 \\
\hline Any Children in Household & 0.724 & 0.447 \\
\hline \multicolumn{3}{|l|}{ Educational Attainment } \\
\hline Less than High School & 0.142 & 0.349 \\
\hline High School & 0.513 & 0.500 \\
\hline Associate Degree & 0.080 & 0.271 \\
\hline Bachelor Degree & 0.174 & 0.379 \\
\hline Graduate Degree & 0.092 & 0.289 \\
\hline \multicolumn{3}{|l|}{ Race } \\
\hline White & 0.758 & 0.428 \\
\hline African American & 0.133 & 0.340 \\
\hline Other & 0.108 & 0.311 \\
\hline \multicolumn{3}{|l|}{ Region } \\
\hline New England & 0.042 & 0.201 \\
\hline Middle Atlantic & 0.132 & 0.338 \\
\hline East North Central & 0.168 & 0.374 \\
\hline West North Central & 0.061 & 0.240 \\
\hline South Atlantic & 0.210 & 0.407 \\
\hline East South Central & 0.057 & 0.232 \\
\hline West South Central & 0.105 & 0.306 \\
\hline Mountain & 0.072 & 0.259 \\
\hline Pacific & 0.152 & 0.359 \\
\hline
\end{tabular}

\section{Copyrights}

Copyright for this article is retained by the author(s), with first publication rights granted to the journal.

This is an open-access article distributed under the terms and conditions of the Creative Commons Attribution license (http://creativecommons.org/licenses/by/4.0/). 